J. Dairy Sci. 92:2248-2258
doi:10.3168/jds.2008-1825
(c) American Dairy Science Association, 2009.

\title{
Genetic evaluation of lactation persistency for five breeds of dairy cattle
}

\author{
J. B. Cole ${ }^{1}$ and D. J. Null \\ Animal Improvement Programs Laboratory, Agricultural Research Service, USDA, Beltsville, MD 20705-2350
}

\begin{abstract}
Cows with high lactation persistency tend to produce less milk than expected at the beginning of lactation and more than expected at the end. Best prediction of lactation persistency is calculated as a function of traitspecific standard lactation curves and linear regressions of test-day deviations on days in milk. Because regression coefficients are deviations from a tipping point selected to make yield and lactation persistency phenotypically uncorrelated it should be possible to use 305-d actual yield and lactation persistency to predict yield for lactations with later endpoints. The objectives of this study were to calculate (co)variance components and breeding values for best predictions of lactation persistency of milk (PM), fat (PF), protein (PP), and somatic cell score (PSCS) in breeds other than Holstein, and to demonstrate the calculation of prediction equations for 400-d actual milk yield. Data included lactations from Ayrshire, Brown Swiss, Guernsey (GU), Jersey (JE), and Milking Shorthorn (MS) cows calving since 1997. The number of sires evaluated ranged from $86(\mathrm{MS})$ to 3,192 (JE), and mean sire estimated breeding value for PM ranged from 0.001 (Ayrshire) to 0.10 (Brown Swiss); mean estimated breeding value for PSCS ranged from -0.01 (MS) to -0.043 (JE). Heritabilities were generally highest for PM (0.09 to 0.15 ) and lowest for PSCS (0.03 to 0.06), with PF and $\mathrm{PP}$ having intermediate values (0.07 to 0.13$)$. Repeatabilities varied considerably between breeds, ranging from 0.08 (PSCS in GU, JE, and MS) to 0.28 (PM in GU). Genetic correlations of PM, PF, and PP with PSCS were moderate and favorable (negative), indicating that increasing lactation persistency of yield traits is associated with decreases in lactation persistency of SCS, as expected. Genetic correlations among yield and lactation persistency were low to moderate and ranged from -0.55 ( $\mathrm{PP}$ in $\mathrm{GU}$ ) to 0.40 (PP in $\mathrm{MS}$ ). Prediction equations for 400-d milk yield were calculated for each breed by regression of both 305-d yield and 305-d yield and lactation persistency on 400-d yield. Goodness-of-fit was very good for both models, but the addition of lac-
\end{abstract}

Received October 23, 2008.

Accepted December 22, 2008.

${ }^{1}$ Corresponding author: john.cole@ars.usda.gov tation persistency to the model significantly improved fit in all cases. Routine genetic evaluations for lactation persistency, as well as the development of prediction equations for several lactation end-points, may provide producers with tools to better manage their herds.

Key words: best prediction, genetic evaluation, persistency

\section{INTRODUCTION}

Persistency of lactation is typically defined as the rate of decline in production after peak milk production has been reached. High lactation persistency is associated with a slow rate of decline in production, whereas low lactation persistency is associated with a rapid rate of decline. Cows with greater lactation persistency are more profitable than average cows when yield and lactation persistency are correlated, although the differences are relatively small unless reproductive performance is very poor (Dekkers et al., 1997). Most previous studies of lactation persistency have focused on its relationships with yield traits, but persistent cows may have lower health care and reproductive costs because of reduced stress at peak lactation (Zimmermann and Sommer, 1973). Muir et al. (2004) reported favorable relationships among lactation persistency and some measures of fertility (e.g., 56-d nonreturn rate), and unfavorable relationships with others (e.g., calving interval). Persistent animals require less energy in early lactation, allowing greater utilization of cheap roughage (Sölkner and Fuchs, 1987). Appuhamy et al. (2007, 2009) reported that diseases tend to significantly affect lactation persistency, rather than persistency affecting disease occurrence, and that there are undesirable genetic correlations among persistency of milk and fat yields and several metabolic diseases. Harder et al. (2006) also reported unfavorable genetic correlations among persistency and metabolic diseases.

Lactation persistency is not currently included in International Bull Evaluation Service evaluations and there considerable variation among countries in how it is evaluated. Gengler (1996) reviewed several definitions of lactation persistency, including those independent of yield, differences between peak yield and yield on some arbitrary day in late lactation, and ratios of peak to late-lactation test-day yields. Druet et al. (2005) and 
Togashi and Lin (2006) have described measures of lactation persistency based on eigenvectors of the genetic (co)variance matrices of random regression models, although their biological interpretation is unclear.

Cole and VanRaden (2006) described the evaluation of persistency of lactation yield for Holstein cows using national data and best prediction (VanRaden, 1997), demonstrating the feasibility of routine genetic evaluations for these traits. Best prediction (BP) of lactation persistency (VanRaden, 1998) is calculated as a function of a trait-specific standard lactation curve and the linear regression of a cow's test-day deviations on DIM. They also suggested that lactation persistency might be used to improve predictions of yield.

Objectives of the current study were to calculate (co) variance components needed for routine evaluations of lactation persistency in Ayrshire (AY), Brown Swiss (BS), Guernsey (GU), Jersey (JE), and Milking Shorthorn (MS) cattle and to develop equations for the prediction of 400-d actual milk yield for each breed from 305-d actual milk yield and persistency of milk yield.

\section{MATERIALS AND METHODS}

\section{Persistency}

For a given lactation, individual daily yield can be modeled as the expected value of a management group plus a deviation from that mean:

$$
\mathrm{y}_{\mathrm{i}}=\mathrm{E}\left(\mathrm{y}_{\mathrm{i}}\right)+\mathrm{t}_{\mathrm{i}},
$$

where $\mathrm{y}_{\mathrm{i}}$ is an individual yield on test-day $\mathrm{i}, \mathrm{E}\left(\mathrm{y}_{\mathrm{i}}\right)$ is the expected yield for an animal in the same management group (Wiggans et al., 1988) on the same test day, and $t_{i}$ is a deviation from the group mean on the same test day. Suppose that $\boldsymbol{\mu}$ is a vector of expected values for each day of lactation for a single trait, $\underset{365 \times 1}{\mathbf{t}}$ is a vector of 365 test-day deviations for the trait, and $\mathbf{t}_{\mathbf{m}}$ is a vector of only the measured deviations (ntd). The means and variances of $\mathbf{t}$ and $\mathbf{t}_{\mathrm{m}}$ are assumed known with $\mathrm{V}(\mathbf{t})=\underset{365 \times 365}{\mathbf{V}}$ and $\mathrm{V}\left(\mathbf{t}_{\mathrm{m}}\right)=\underset{\text { ntd } \times \text { ntd }}{\mathbf{V}_{\mathbf{m}}}$. The covariance between $\mathbf{t}$ and $\mathbf{t}_{\mathbf{m}}, \underset{365 \times \text { ntd }}{\mathbf{C}}$, is assumed known and is calculated using a mathematical function that accounts for daily measurement error, biological changes over time, and parity (Cole et al., 2009). The elements of $\mathbf{t}$ are calculated using herd-specific lactation curves whose average yields may vary. Vectors and matrices are dimensioned for $365 \mathrm{~d}$ rather than $305 \mathrm{~d}$ because test days falling between 305 and $365 \mathrm{~d}$ are used to improve the prediction of 305-d yield.
Lactation persistency may be measured by multiplying test-day deviations by a linear function of DIM (VanRaden, 1998). Let $\underset{365 \times 1}{\mathbf{d}}$ represent a vector whose elements, $d_{i}$, represent the DIM on the ith day of lactation. A measure of lactation persistency that is phenotypically uncorrelated with lactation yield may be obtained by defining coefficients $\mathrm{q}_{\mathrm{i}}=\mathrm{d}_{\mathrm{i}}-\mathrm{d}_{0}$, where $\mathrm{d}_{0}$ is a constant which acts as a tipping point between yields in early and late lactation and the vector $\underset{365 \times 1}{\mathbf{q}}$ indicates how far apart in time individual DIM are from the trait-dependent tipping points. Lactation persistency is then calculated as:

$$
\mathrm{p}=\mathbf{d}^{\prime} \boldsymbol{\mu}-\mathrm{d}_{0} \mathrm{E}(\mathbf{y})+\mathbf{q}^{\prime} \mathbf{C V}_{\mathbf{m}}{ }^{-1} \mathrm{t}_{\mathrm{m}}
$$

where $\mathrm{p}$ is the predicted lactation persistency, which represents the component of lactation persistency that is independent of yield. Values of $\mathrm{d}_{0}$ were calculated separately for first and later parities, and the same $\mathrm{d}_{0}$ were used for all breeds. The tipping points are distinct from the lactation curves $\left(\mathbf{d}^{\prime} \boldsymbol{\mu}\right)$, and are used only in the calculation of persistency. Lactation persistency was converted to a unit normal scale with a mean of 0 and a variance of 1 .

The $\mathbf{d}^{\prime} \boldsymbol{\mu}$ term represents a breed- and parity-specific standard lactation curve, $\mathrm{d}_{0} \mathrm{E}(\mathbf{y})$ represents the expected yield of a cow in the same breed-parity group, and the $\mathbf{q}^{\prime} \mathbf{C V}_{\mathrm{m}}{ }^{-1} \mathrm{t}_{\mathrm{m}}$ term represents an individual cow's expected deviation from the herd test-day average. Lactation persistency may be thought of as the regression of adjusted yield deviations on DIM for a particular trait, with cows producing greater yield in the first part of lactation (DIM $<\mathrm{d}_{0}$ ) having negative lactation persistency and cows producing greater yield in the second part of lactation (DIM $>\mathrm{d}_{0}$ ) having positive lactation persistency. Additional details on the derivation of lactation persistency are provided in Cole and VanRaden (2006).

\section{Data}

Data consisted of lactations for AY, BS, GU, JE, and MS dairy cattle initiated by calvings on or after January 1, 1997, stored in the national dairy database (NDDB) at the Animal Improvement Programs Laboratory (USDA, Beltsville, MD). All cows were required to have a first lactation, only the first 5 lactations were used, and lactation persistency that exceeded \pm 4.0 (4 SD) was rounded to an absolute value of \pm 4.0 . Days open less than 50 were set to 50 , and days open greater than 250 were set to 250 . Phenotypic reliabilities, the ratio of predicted to true lactation persistency (VanRaden, 1997), of at least $50 \%$ were required for all milk (PM), 
Table 1. Number of cows, number of lactations, first lactation records as a proportion of all lactations, and means and SD of yield and persistency for milk, fat, protein, and SCS

\begin{tabular}{|c|c|c|c|c|c|c|}
\hline Breed $^{1}$ & Trait & Cows & \multicolumn{2}{|c|}{ Lactations } & $\begin{array}{c}\text { Yield } \\
(\text { mean } \pm \mathrm{SD})\end{array}$ & $\begin{array}{c}\text { Persistency }^{2} \\
(\text { mean } \pm \mathrm{SD})\end{array}$ \\
\hline \multirow{2}{*}{$\mathrm{AY}$} & Protein (kg) & 16,417 & 34,712 & 46 & $251 \pm 52$ & $-0.19 \pm 0.87$ \\
\hline & SCS & 15,391 & 31,900 & 46 & $2.92 \pm 1.21$ & $0.27 \pm 0.77$ \\
\hline \multirow[t]{2}{*}{ BS } & Milk (kg) & 39,035 & 80,628 & 46 & $9,456 \pm 2,044$ & $0.10 \pm 1.05$ \\
\hline & SCS & 38,350 & 78,515 & 46 & $2.98 \pm 1.24$ & $0.22 \pm 0.84$ \\
\hline \multirow[t]{4}{*}{ GU } & Milk (kg) & 24,544 & 48,563 & 49 & $7,525 \pm 1,699$ & $-0.17 \pm 0.85$ \\
\hline & Fat $(\mathrm{kg})$ & 24,539 & 48,557 & 49 & $332 \pm 71$ & $0.36 \pm 0.90$ \\
\hline & Protein (kg) & 24,539 & 48,557 & 49 & $247 \pm 52$ & $0.17 \pm 0.85$ \\
\hline & SCS & 24,365 & 47,934 & 49 & $3.13 \pm 1.38$ & $0.11 \pm 0.84$ \\
\hline \multirow[t]{2}{*}{$\mathrm{JE}$} & Milk (kg) & 265,034 & 785,519 & 44 & $7,872 \pm 1,606$ & $0.11 \pm 0.79$ \\
\hline & Fat $(\mathrm{kg})$ & 265,034 & 776,402 & 44 & $361 \pm 75$ & $0.46 \pm 0.90$ \\
\hline MS & SCS & 5,494 & 11,029 & 47 & $3.02 \pm 1.27$ & $0.29 \pm 0.81$ \\
\hline
\end{tabular}

${ }^{1} \mathrm{AY}=$ Ayrshire, BS = Brown Swiss, GU = Guernsey, JE = Jersey, MS = Milking Shorthorn.

${ }^{2}$ Persistency is standardized, with a mean of 0 and a SD of 1 .

fat $(\mathbf{P F})$, and protein $(\mathbf{P P})$ persistencies. Descriptive statistics of the data sets are provided in Table 1. All analyses were conducted on a within-breed basis.

The repeatability animal model used for both (co) variance components estimation and breeding value prediction was

$$
y_{\mathrm{ijkl}}=\operatorname{hys}_{\mathrm{i}}+\mathrm{lac}_{\mathrm{j}}+\mathrm{a}_{\mathrm{k}}+\mathrm{pe}_{\mathrm{k}}+\beta\left(\mathrm{do}_{\mathrm{jk}}\right)+\mathrm{e}_{\mathrm{ijkl}} \text {, }
$$

where $\mathrm{y}_{\mathrm{ijkl}}=$ persistency of milk, fat, protein, or SCS, hys $_{\mathrm{i}}=$ fixed effect of herd-year-season of calving i, $\mathrm{lac}_{\mathrm{j}}=$ fixed effect of lactation $\mathrm{j}, \mathrm{a}_{\mathrm{k}}=$ random additive genetic effect of animal $\mathrm{k}, \mathrm{pe}_{\mathrm{k}}=$ random permanent environmental effect of animal $\mathrm{k}, \mathrm{do}_{\mathrm{jk}}=$ days open for lactation $\mathrm{j}$ of animal $\mathrm{k}$, and $\mathrm{e}_{\mathrm{ijkl}}=$ random residual error. The model did not include a regression on 305-d yield because lactation persistency and 305-d yield were already defined to be independent.

(Co)variance components were estimated within breeds using single-trait animal models and restricted maximum likelihood on the full data sets using the REMLF90 software package (Misztal et al., 2002). Standard estimates of the (co)variance components are not available from the EM algorithm (Dempster et al., 1977) as implemented in REMLF90 (Misztal, 2008). Approximate reliabilities of sire PTA for lactation persistency were calculated using the ACCF90 package (Misztal et al., 2002); yield reliabilities were obtained from the national genetic evaluation system. Complete pedigrees for each animal were extracted from the NDDB and combined into breed-specific files. Pairwise genetic and residual correlations among the 4 lactation persistency traits were estimated for each breed using a series of 6 bivariate models. Genetic correlations among yield and lactation persistency traits were obtained using 16 additional bivariate models. Best linear unbiased predictions of breeding values were obtained by fitting single-trait animal models to the full data set for each lactation persistency trait with the estimated (co)variance components using the BLUP90IOD software package (Misztal et al., 2002).

\section{Prediction of Yields Beyond 305 DIM}

Given that BP of 305-d actual yield and lactation persistency are phenotypically uncorrelated (Cole and VanRaden, 2006) it should be possible to predict yield beyond 305 DIM as some function of the two. Lactation persistency is forced to be independent of 305-d yield but not yield beyond $305 \mathrm{~d}$, and cows with high persistency may have higher yields in long lactations. Producers may use prediction equations to compare alternative management decisions that potentially affect lactation lengths, such as voluntary waiting periods and dry-off dates. Best prediction can calculate yields for lactations of any reasonable length (Cole et al., 2009), but that methodology is not implemented in any on-farm management software. Equations were 
Table 2. Estimated additive genetic variances $\left(\sigma_{\mathrm{a}}{ }^{2}\right)$, permanent environmental variances $\left(\sigma_{\mathrm{pe}}{ }^{2}\right)$, residual variances $\left(\sigma_{\mathrm{e}}{ }^{2}\right)$, heritabilities $\left(\mathrm{h}^{2}\right)$, and repeatabilities $(\mathrm{r})$ for persistency of milk $(\mathrm{PM})$, fat $(\mathrm{PF})$, and protein (PP) yields and SCS (PSCS)

\begin{tabular}{lllllll}
\hline Breed $^{1}$ & Trait & $\sigma_{\mathrm{a}}{ }^{2}$ & $\sigma_{\mathrm{pe}}{ }^{2}$ & $\sigma_{\mathrm{e}}{ }^{2}$ & $\mathrm{~h}^{2}$ & $\mathrm{r}$ \\
\hline AY & PM & 0.08 & 0.06 & 0.42 & 0.15 & 0.26 \\
& PF & 0.06 & 0.05 & 0.43 & 0.12 & 0.21 \\
& PP & 0.06 & 0.06 & 0.39 & 0.13 & 0.24 \\
BS & PSCS & 0.03 & 0.04 & 0.51 & 0.06 & 0.12 \\
& PM & 0.08 & 0.06 & 0.60 & 0.10 & 0.19 \\
& PF & 0.07 & 0.07 & 0.69 & 0.08 & 0.17 \\
& PP & 0.06 & 0.06 & 0.62 & 0.08 & 0.17 \\
GU & PSCS & 0.04 & 0.04 & 0.60 & 0.06 & 0.12 \\
& PM & 0.09 & 0.05 & 0.37 & 0.18 & 0.28 \\
& PF & 0.06 & 0.06 & 0.47 & 0.10 & 0.20 \\
& PP & 0.06 & 0.05 & 0.41 & 0.12 & 0.21 \\
& PSCS & 0.02 & 0.04 & 0.63 & 0.03 & 0.08 \\
& PM & 0.06 & 0.07 & 0.35 & 0.13 & 0.27 \\
& PF & 0.06 & 0.07 & 0.55 & 0.09 & 0.19 \\
& PP & 0.06 & 0.06 & 0.43 & 0.11 & 0.23 \\
MS & PSCS & 0.02 & 0.02 & 0.52 & 0.04 & 0.08 \\
& PM & 0.06 & 0.10 & 0.44 & 0.09 & 0.26 \\
& PF & 0.04 & 0.07 & 0.43 & 0.07 & 0.20 \\
& PP & 0.06 & 0.08 & 0.40 & 0.10 & 0.25 \\
& PSCS & 0.03 & 0.02 & 0.61 & 0.05 & 0.08 \\
\hline
\end{tabular}

${ }^{1} \mathrm{AY}=$ Ayrshire, $\mathrm{BS}=$ Brown Swiss, GU $=$ Guernsey, JE $=$ Jersey, MS $=$ Milking Shorthorn.

developed to predict 400-d milk yield from either 305-d milk yield or 305-d milk yield plus lactation persistency for 6 breeds of dairy cattle. Jersey data were used to further investigate the predictive ability of lactation persistency with increasing lactation length.

Data for AY, BS, GU, JE, and MS were extracted from the NDDB as described by Cole et al. (2009), with the additional requirement that lactations were at least $400 \mathrm{~d}$ long. Holstein (HO) cow data were extracted from the data file used by Dematawewa et al. (2007). Lactation persistency, 305-d, and 400-d actual milk yields were obtained using the BESTPRED program (Cole and VanRaden, 2007). The response variable of interest was the amount of milk produced between 305 and 400 DIM, which avoids part-whole confounding when regressing on 305-d yield. Two linear regressions, a reduced model with only 305-d yield and a full model including 305-d yield and lactation persistency as predictors, were fit to the data:

$$
\mathrm{y}_{400-305}=\mathrm{b}_{1} \mathrm{y}_{305}+\mathrm{e}
$$

and

$$
\mathrm{y}_{400-305}=\mathrm{b}_{1} \mathrm{y}_{305}+\mathrm{b}_{2} \mathrm{p}_{305}+\mathrm{e},
$$

where $\mathrm{y}_{305}$ is the actual 305-d yield, $\mathrm{p}_{305}$ is the persistency of 305-d yield, $\mathrm{y}_{400-305}$ is the difference between the 400-d and 305-d yields, $\mathrm{b}_{1}$ and $\mathrm{b}_{2}$ are regression coefficients, and e is the random residual error term.
Goodness-of-fit for each model was assessed using the $\mathrm{R}^{2}$ statistic, and the change in $\mathrm{R}^{2}$ between the reduced and full models was used to determine how much the prediction of $\mathrm{y}_{400-305}$ was improved by the inclusion of lactation persistency in the model. The full and reduced models also were compared using an $F$-statistic constructed from the residual sums of squares and degrees of freedom from each model (Cook and Weisberg, 1998), which is equivalent to testing the null hypothesis $\mathrm{b}_{2}=0$.

A similar analysis was used for milk, fat, and protein yield in JE to determine the predictive ability of lactation persistency with increasing lactation length. The response variables of interest were the amount of milk, fat, and protein produced between $305 \mathrm{~d}$ and $999 \mathrm{~d}$ in 100-d intervals (305 d to $400 \mathrm{~d}$, 305 d to 500 d, etc.). Goodness-of-fit between models was compared using the $F$-test described above.

\section{RESULTS}

\section{Heritability and Repeatability}

Additive genetic variances, permanent environmental variances, residual variances, heritabilities, and repeatabilities for persistency of milk, fat, and protein yields and SCS (PSCS) are presented in Table 2. Heritabilities represent the additive genetic variance of lactation persistency that is independent of yield for a trait and defined to have phenotypic variance of 1 . Heritabilities for lactation persistency ranged from 0.07 to 0.18 for production traits, and from 0.03 to 0.06 for SCS, and were generally highest for PM (0.09 to 0.15) and lowest for PSCS, with $\mathrm{PF}$ and PP having intermediate values (0.07 to 0.13$)$. Repeatabilities varied considerably between breeds, ranging from 0.08 (PSCS in GU, JE, and $\mathrm{MS})$ to 0.28 (PM in GU). These estimates are similar to those reported by Cole and VanRaden (2006) for yield and SCS in Holsteins using BP. Gengler (1995) reported similar heritabilities and repeatabilities for PM $(0.14,0.26), \operatorname{PF}(0.06,0.15)$, and PP $(0.04,0.10)$ for measures of lactation persistency adjusted such that they were phenotypically uncorrelated with $305-\mathrm{d}$ yield. These estimates are lower than others reported in the literature (Danell, 1982; Jamrozik et al., 1998; Strabel et al., 2001; Jakobsen et al., 2002), and may be due in part to differences in trait definition.

No estimates of PSCS other than the Holstein results of Cole and VanRaden (2006) were found in the literature. The low estimates of heritability and repeatability in the current and previous studies indicate that environmental factors have much larger effects on SCS at given stages of lactation than does PSCS. 
Table 3. Phenotypic correlations of persistency for milk (PM), fat (PF), protein (PP), and SCS (PSCS) with 305-d milk, fat, and protein yields and SCS

\begin{tabular}{|c|c|c|c|c|c|}
\hline \multirow[b]{2}{*}{ Breed $^{1}$} & \multirow[b]{2}{*}{ Persistency trait } & \multicolumn{4}{|c|}{ Yield trait } \\
\hline & & Milk (kg) & Fat $(\mathrm{kg})$ & Protein (kg) & SCS \\
\hline \multirow[t]{4}{*}{$\mathrm{AY}$} & PM & 0.11 & 0.14 & 0.12 & -0.12 \\
\hline & $\mathrm{PF}$ & 0.14 & 0.11 & 0.16 & -0.13 \\
\hline & $\mathrm{PP}$ & 0.14 & 0.18 & 0.14 & -0.13 \\
\hline & PSCS & 0.03 & 0.02 & 0.03 & 0.02 \\
\hline \multirow[t]{4}{*}{ BS } & PM & 0.20 & 0.20 & 0.22 & -0.10 \\
\hline & $\mathrm{PF}$ & 0.17 & 0.13 & 0.19 & -0.11 \\
\hline & PP & 0.23 & 0.23 & 0.23 & -0.12 \\
\hline & PSCS & 0.01 & 0.00 & 0.01 & 0.03 \\
\hline \multirow[t]{4}{*}{ GU } & $\mathrm{PM}$ & 0.07 & 0.09 & 0.09 & -0.10 \\
\hline & $\mathrm{PF}$ & 0.16 & 0.14 & 0.18 & -0.11 \\
\hline & $\mathrm{PP}$ & 0.13 & 0.16 & 0.13 & -0.11 \\
\hline & PSCS & 0.01 & -0.01 & 0.00 & 0.06 \\
\hline \multirow[t]{4}{*}{ JE } & $\mathrm{PM}$ & 0.09 & 0.12 & 0.10 & -0.06 \\
\hline & $\mathrm{PF}$ & 0.16 & 0.14 & 0.18 & -0.07 \\
\hline & $\mathrm{PP}$ & 0.10 & 0.13 & 0.10 & -0.07 \\
\hline & PSCS & 0.04 & 0.04 & 0.04 & -0.06 \\
\hline \multirow[t]{4}{*}{ MS } & PM & 0.14 & 0.16 & 0.17 & -0.09 \\
\hline & $\mathrm{PF}$ & 0.12 & 0.06 & 0.15 & -0.10 \\
\hline & PP & 0.14 & 0.16 & 0.15 & -0.10 \\
\hline & PSCS & 0.01 & -0.01 & 0.00 & -0.01 \\
\hline
\end{tabular}

${ }^{1} \mathrm{AY}=$ Ayrshire, BS $=$ Brown Swiss, GU = Guernsey, JE = Jersey, MS = Milking Shorthorn.

\section{Correlations Among Persistency and Yield Traits}

The phenotypic (Table 3) and genetic (Table 4) correlations among lactation persistency and yield varied across breeds, as expected. The expectation of the phenotypic correlation among traits is 0 when breed-specific tipping points were calculated, which was verified by Cole and VanRaden (2006) for HO data and in the current study (data not shown). Phenotypic correlations of PM with milk, fat, and protein yield were positive in all breeds, although the magnitude of the correlations varied considerably. The tipping points used to calculate lactation persistency were calculated using Holstein data, so phenotypic correlations among yield and lactation persistency will only be 0 for Holsteins or breeds with lactation curves very similar to Holsteins. The breed that differed most from expectations was Brown Swiss, and that difference is consistent with the finding of Cole et al. (2009) that the shape parameters of BS lactation curves differ most from those of HO. In some breeds, PM had the highest phenotypic correlations with yield (MS), and in others it was $\mathrm{PF}$ or PP (AY, GU, JE, and BS). These results are consistent with lactation curves that differ between breeds and traits. Phenotypic correlations of milk, fat, and protein with SCS were negative in all breeds, and the correlations of PSCS and SCS were close to 0. Persistency of SCS had low correlations with milk, fat, and protein yield across breeds.
Genetic correlations of PM with milk, fat, and protein yield varied widely across breeds and were not consistent with respect to sign, ranging from -0.55 $\left(\mathrm{r}_{\mathrm{PP} \text {,protein }}\right.$ in $\left.\mathrm{GU}\right)$ to 0.40 ( $\mathrm{r}_{\mathrm{PF} \text {,protein }}$ in $\left.\mathrm{MS}\right)$. Genetic correlations even differed within persistency trait by breed, unlike the phenotypic correlations, and reflect genetic differences among breeds in lactation curves for the yield traits. Somatic cell score had negative genetic correlations with PM, PF, and PP across breeds, and those correlations ranged from -0.50 ( $\mathrm{r}_{\mathrm{PP}, \mathrm{SCS}}$ in $\mathrm{MS}$ ) to $-0.05\left(\mathrm{r}_{\mathrm{PP}, \mathrm{SCS}}\right.$ in $\left.\mathrm{BS}\right)$. This may reflect the undesirable influence of mastitis occurring after 100 DIM on lactation persistency (Appuhamy et al., 2007) in which intramammary infections produce increased SCS and decreased persistency of yield. However, the relationship between mastitis and lactation persistency is complex, depending on factors such as time of occurrence of mastitis and the number of cases reported in a lactation.

\section{Correlations Among Persistency Traits}

Genetic and phenotypic correlations among persistency of milk, fat, and protein yields and SCS are presented for each breed in Table 5. Results for milk, fat, and protein were similar to those presented by Cole and VanRaden (2006). The negative correlations between yield and SCS are consistent with the deleterious effect of poor mammary health on production (Rajala-Schultz et al., 1999; Appuhamy et al., 2007). 
Table 4. Genetic correlations of persistency for milk (PM), fat (PF), protein (PP), and SCS (PSCS) with 305-d milk, fat, protein, and SCS yields

\begin{tabular}{|c|c|c|c|c|c|}
\hline \multirow[b]{2}{*}{ Breed $^{1}$} & \multirow[b]{2}{*}{ Persistency trait } & \multicolumn{4}{|c|}{ Yield trait } \\
\hline & & Milk (kg) & Fat (kg) & Protein (kg) & SCS \\
\hline \multirow[t]{4}{*}{ AY } & PM & 0.01 & 0.06 & -0.12 & -0.28 \\
\hline & $\mathrm{PF}$ & 0.29 & 0.19 & 0.20 & -0.32 \\
\hline & PP & 0.01 & 0.02 & -0.18 & -0.29 \\
\hline & PSCS & -0.34 & 0.11 & 0.00 & 0.64 \\
\hline \multirow[t]{4}{*}{ BS } & PM & 0.19 & 0.06 & 0.10 & -0.32 \\
\hline & $\mathrm{PF}$ & 0.07 & 0.26 & 0.23 & -0.05 \\
\hline & $\mathrm{PP}$ & 0.09 & 0.09 & 0.09 & -0.05 \\
\hline & PSCS & 0.00 & 0.00 & 0.00 & 0.02 \\
\hline \multirow[t]{4}{*}{ GU } & PM & -0.25 & -0.19 & -0.38 & -0.40 \\
\hline & $\mathrm{PF}$ & 0.15 & -0.16 & -0.09 & -0.29 \\
\hline & $\mathrm{PP}$ & -0.27 & -0.34 & -0.55 & -0.44 \\
\hline & PSCS & -0.53 & 0.87 & 0.00 & 0.05 \\
\hline \multirow[t]{4}{*}{ JE } & PM & -0.10 & 0.12 & 0.13 & -0.17 \\
\hline & $\mathrm{PF}$ & 0.27 & 0.18 & 0.26 & -0.07 \\
\hline & PP & -0.02 & 0.01 & -0.14 & -0.14 \\
\hline & PSCS & -0.17 & -0.21 & -0.19 & 0.13 \\
\hline \multirow[t]{4}{*}{ MS } & PM & -0.03 & -0.04 & -0.18 & -0.42 \\
\hline & $\mathrm{PF}$ & 0.21 & 0.27 & 0.40 & -0.30 \\
\hline & $\mathrm{PP}$ & -0.04 & 0.05 & -0.21 & -0.50 \\
\hline & PSCS & 0.67 & 0.53 & 0.91 & 0.63 \\
\hline
\end{tabular}

${ }^{1} \mathrm{AY}=$ Ayrshire, $\mathrm{BS}=$ Brown Swiss, GU $=$ Guernsey, JE $=$ Jersey, MS = Milking Shorthorn.

\section{Correlations Among Persistency and Lifetime Performance Traits}

To investigate relationships among lactation persistency and other traits of economic significance sire PTA for PM, PF, PP, and PSCS were correlated with PTA for daughter pregnancy rate (DPR), productive life (PL), and lifetime net merit, cheese merit, and fluid merit (VanRaden, 2004; VanRaden et al., 2004, 2006). Bulls were included if they were born on or after January 1, 1990, and had a reliability of at least $75 \%$ for a particular performance trait. Because of the small number of available AY, GU, and MS bulls, results are presented only for BS and JE. None of the persistency traits had a significant correlation with DPR, which may be a consequence of including days open in the model for lactation persistency. Productive life had significant, positive correlations $(P<0.05)$ with $\mathrm{PM}$ and $\mathrm{PP}$ in $\mathrm{BS}(\mathrm{n}=54)$ and with $\mathrm{PM}, \mathrm{PF}$, and $\mathrm{PP}$ in JE $(\mathrm{n}=230)$. Correlations with PL ranged from 0.25 to 0.35 for BS, and 0.20 to 0.23 for JE. All 3 economic indices had significant correlations $(P<0.05)$ with the persistency traits in BS $(\mathrm{n}=222)$ and JE $(\mathrm{n}=$ 1,012). Persistency of milk, fat, and protein had correlations with the economic indices that were positive and ranged from 0.19 to 0.29 in $\mathrm{BS}$ and 0.20 to 0.34 in JE. The correlations of the merit traits with PSCS were negative in both breeds, averaging -0.27 in BS and -0.17 in JE.

\section{Sire Evaluations}

Summary statistics for sire evaluations by breed are presented in Table 6. Genetic trends, estimated by regression of PTA on sire birth year, were near 0 and

Table 5. Estimated genetic (above the diagonal) and phenotypic (below the diagonal) correlations for persistency of milk (PM), fat $(\mathrm{PF})$, and protein (PP) yields and SCS (PSCS)

\begin{tabular}{llrrrr}
\hline Breed $^{1}$ & Trait & PM & \multicolumn{1}{c}{ PF } & \multicolumn{1}{c}{ PP } & PSCS \\
\hline AY & PM & & 0.87 & 0.94 & -0.37 \\
& PF & 0.80 & & 0.87 & -0.31 \\
& PP & 0.93 & 0.82 & & -0.32 \\
BS & PSCS & -0.22 & -0.19 & -0.19 & \\
& PM & & 0.84 & 0.88 & -0.52 \\
& PF & 0.76 & & 0.80 & -0.50 \\
& PP & 0.91 & 0.79 & & -0.44 \\
GU & PSCS & -0.21 & -0.15 & -0.17 & \\
& PM & & 0.78 & 0.89 & -0.38 \\
& PF & 0.76 & & 0.84 & -0.52 \\
& PP & 0.90 & 0.81 & & -0.56 \\
JE & PSCS & -0.18 & -0.15 & -0.15 & \\
& PM & & 0.79 & 0.90 & -0.44 \\
& PF & 0.76 & & 0.80 & -0.50 \\
& PP & 0.89 & 0.81 & & -0.43 \\
MS & PSCS & -0.18 & -0.14 & -0.16 & \\
& PM & & 0.82 & 0.94 & -0.52 \\
& PF & 0.77 & & 0.84 & -0.52 \\
& PP & 0.92 & 0.79 & & -0.58 \\
\hline & PSCS & -0.21 & -0.16 & -0.18 & \\
\hline
\end{tabular}

${ }^{1} \mathrm{AY}=$ Ayrshire, $\mathrm{BS}=$ Brown Swiss, GU $=$ Guernsey, JE $=$ Jersey, MS $=$ Milking Shorthorn. 
Table 6. Summary statistics of sire evaluations for persistency and yield of milk, fat, and protein yield and SCS

\begin{tabular}{|c|c|c|c|c|c|c|c|c|c|c|c|}
\hline Breed $^{1}$ & Trait & \multicolumn{5}{|c|}{ Persistency } & \multicolumn{5}{|c|}{ Yield } \\
\hline \multirow[t]{3}{*}{ AY } & Milk (kg) & 610 & $0.001 \pm 0.15$ & -0.48 & 0.68 & 52 & 610 & $-298 \pm 568$ & $-2,065$ & 1,281 & 67 \\
\hline & Protein (kg) & 610 & $-0.007 \pm 0.14$ & -0.51 & 0.56 & 52 & 610 & $-7 \pm 16$ & -58 & 35 & 67 \\
\hline & SCS & 610 & $-0.029 \pm 0.08$ & -0.39 & 0.30 & 52 & 482 & $2.97 \pm 0.16$ & 2.40 & 3.85 & 66 \\
\hline BS & Milk (kg) & 923 & $0.102 \pm 0.15$ & -0.36 & 0.67 & 43 & 923 & $-419 \pm 852$ & $-3,110$ & 1,708 & 77 \\
\hline \multirow[t]{4}{*}{ GU } & Milk (kg) & 918 & $0.041 \pm 0.14$ & -0.60 & 0.47 & 49 & 918 & $-751 \pm 867$ & $-3,189$ & 1,761 & 81 \\
\hline & Fat $(\mathrm{kg})$ & 918 & $0.065 \pm 0.14$ & -0.36 & 0.50 & 49 & 918 & $-29 \pm 35$ & -122 & 56 & 81 \\
\hline & Protein (kg) & 918 & $0.053 \pm 0.12$ & -0.40 & 0.46 & 49 & 918 & $-22 \pm 26$ & -99 & 43 & 80 \\
\hline & SCS & 918 & $-0.027 \pm 0.06$ & -0.26 & 0.30 & 49 & 883 & $2.97 \pm 0.16$ & 2.55 & 3.58 & 66 \\
\hline \multirow[t]{2}{*}{ JE } & Milk (kg) & 3,192 & $0.045 \pm 0.15$ & -0.70 & 0.75 & 58 & 3,192 & $-498 \pm 917$ & $-3,944$ & 1,722 & 77 \\
\hline & Fat $(\mathrm{kg})$ & 3,192 & $0.019 \pm 0.15$ & -0.67 & 0.75 & 59 & 3,192 & $-17 \pm 35$ & -154 & 98 & 77 \\
\hline MS & SCS & 86 & $-0.009 \pm 0.08$ & -0.17 & 0.18 & 57 & 77 & $2.96 \pm 0.17$ & 2.47 & 3.35 & 66 \\
\hline
\end{tabular}

${ }^{1} \mathrm{AY}=$ Ayrshire, BS = Brown Swiss, GU = Guernsey, JE = Jersey, MS = Milking Shorthorn.

${ }^{2} \mathrm{Rel}=$ average reliability of sire PTA.

nonsignificant $(P>0.10)$ for all traits in each breed (data not shown). Selection for improved yield has not resulted in increased lactation persistency despite moderately large genetic correlations between some persistency and yield traits (e.g., PM and protein yield in GU). Reliabilities of sire PTA for lactation persistency in all breeds were lower than those of the yield traits, which is expected because the persistency traits have lower heritabilities than the corresponding yield traits.

\section{Prediction of Yields Beyond 305 DIM}

Prediction equations for the amount of milk produced between d 305 and 400 of lactation, $\mathrm{y}_{400-305}$, for each breed are presented in Table 7 . The regression coefficients from the reduced model were similar in all breeds, ranging from 0.22 in $\mathrm{AY}$ to 0.25 in $\mathrm{BS}$, and this term represents a straightforward scaling factor which accounts for differences in 305-d yield across breeds. Goodness-of-fit as assessed by the coefficient of determination statistic was very good in all cases $\left(\mathrm{R}^{2}>\right.$ 0.95). Adding the lactation persistency term had only a small effect on goodness-of-fit, increasing the coefficient of determination by 0.0026 to 0.0054 , but provided a significantly better fit to the data in all cases $(P<$ 0.0001). Regression coefficients for 305-d yield were similar between the full and reduced models. Ayrshires, GU, HO, and JE had similar regression coefficients for lactation persistency ranging from 332.47 (JE) to $379.24(\mathrm{GU})$, suggesting that the influence of lactation persistency on $\mathrm{y}_{400-305}$ is similar in those breeds. The lactation persistency term represents the rate at which production changes as lactations extend beyond $305 \mathrm{~d}$; positive lactation persistency adds yield to an extended lactation compared with an average cow, and negative lactation persistency subtracts yield. For example, a BS cow that is +2 for $\mathrm{PM}$ will produce $1,138 \mathrm{~kg}$ more milk between 305 and $400 \mathrm{~d}$ than a cow with a persistency of zero, whereas a BS cow that is -2 for PM will produce $1,035 \mathrm{~kg}$ less milk over the same time period. Ayrshires, GU, and JE had similar $\mathrm{y}_{400-305}(1,686$ to $1,809 \mathrm{~kg})$, as did BS, HO, and MS (2,070 to $2,466 \mathrm{~kg})$. These results suggest that 305-d milk yield alone is as good a predictor of milk yield beyond $305 \mathrm{~d}$ as yield and lactation persistency together. This would be the case if the phenotypic correlation between lactation persistency and the amount of milk produced in the 305 to 400 DIM interval was 0 .

Full and reduced regression models were fitted to JE milk, fat, and protein data in 100-d intervals from 305 to 999 DIM (306-400, 401-500, 501-600, 601-700, 701-800, 801-900, and 901-999) identified by the endpoint of the interval to determine if the predictive ability of 305-d yield and lactation persistency differ across length of lactation and trait. It was expected that lactation persistency would provide more information as lactations increased in length. However, results from this extended analysis were similar to those from the milk analysis in individual breeds (Table 8). Differences between time periods were small, and there were no 
Table 7. Prediction equations for $305-\mathrm{d}$ to 400 -d milk yield using $305-\mathrm{d}$ milk yield and persistency ${ }^{1}$

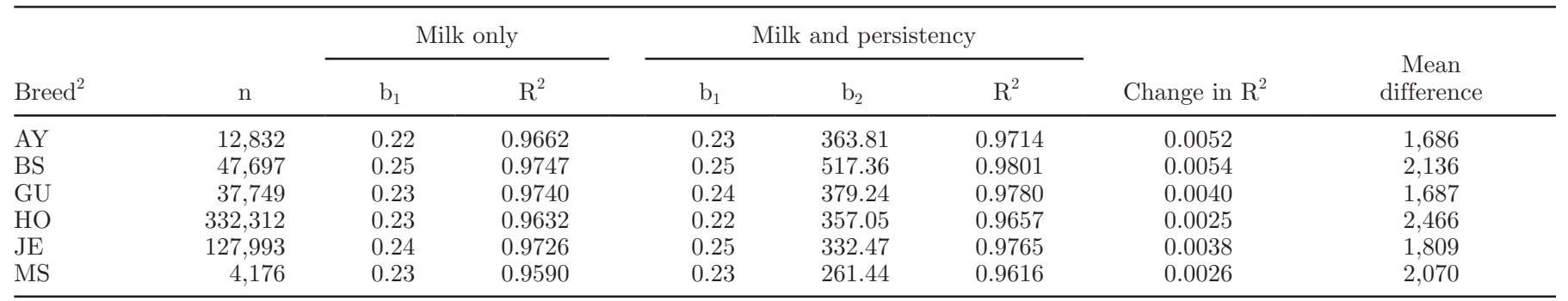

${ }^{1}$ In all cases, the full model including milk yield and persistency provided a significantly better fit to the data $(P<0.0001)$ than did the reduced model including only milk yield.

${ }^{2} \mathrm{AY}=$ Ayrshire, $\mathrm{BS}=$ Brown Swiss, GU $=$ Guernsey, JE $=$ Jersey, MS = Milking Shorthorn.

differences in the relative predictive abilities of $305-\mathrm{d}$ yield and lactation persistency across traits.

\section{DISCUSSION}

Lactation persistency as defined by Cole and VanRaden (2006) is useful as a measure of the shape of the lactation curve independent of 305-d yield. The results of Jamrozik et al. (1998) and van der Linde et al. (2000) suggest that lactation curves and persistencies differ between lactations, and differences probably exist between early- and late-maturing breeds. This was confirmed by Cole et al. (2009), who estimated lactation curves for first and later parities in 6 breeds of dairy cattle and found that parameters describing the shapes of the curves can vary considerably. Breed- and parityspecific lactation curves are used in BP calculations (Cole and VanRaden, 2007), and the resulting test-day deviations are used in the calculation of both lactation yields and persistency.

The mean lactation persistencies in Table 1 are not 0 because HO rather than breed-specific tipping points were used, placing all cows on a HO base. It is not technically difficult to use breed- and parity-specific tipping points, but if that is done animals can be compared only to animals in the same breed-parity group. Results obtained from analyses using breed- and parity-specific tipping points (data not shown) indicated that differences between first and later lactations were generally much larger than differences between breeds. The use

Table 8. Prediction equations for 400-d through 999-d Jersey milk, fat, and protein yield using 305-d milk yield and persistency by 100-d interval $^{1}$

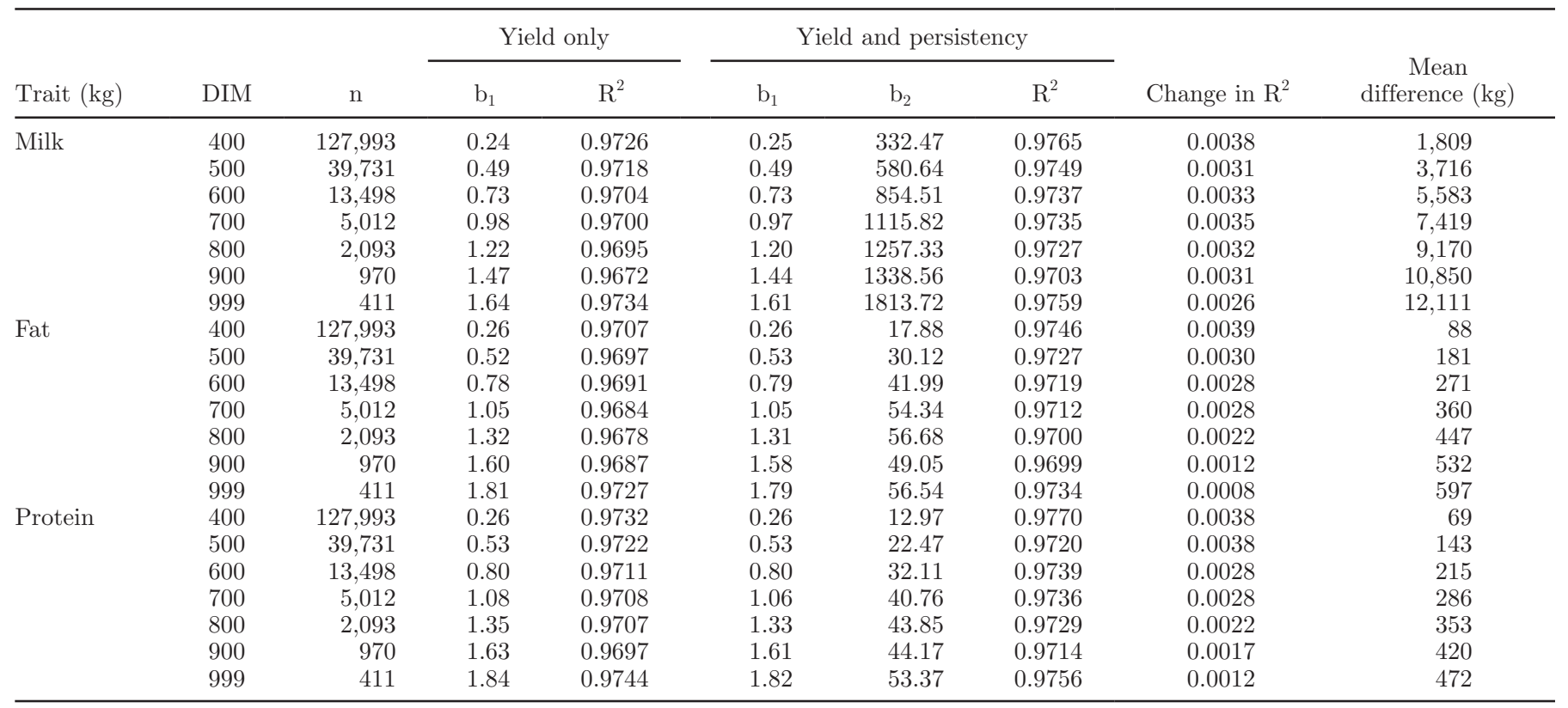

${ }^{1}$ In all cases, the full model including milk yield and persistency provided a significantly better fit to the data $(P<0.0001)$ than did the reduced model including only milk yield. 
of a common set of tipping points also ensures that comparable phenotypes are generated for use in the all-breed genetic evaluation system (VanRaden et al., 2007); US type traits are not evaluated in an all-breeds model because the traits are measured differently in each breed, and use of common tipping points avoids that problem with lactation persistency.

Holstein tipping points were re-estimated several years after the introduction of BP (VanRaden, 1997) and were found to have changed over time (Cole and VanRaden, 2006). Updated variance components were almost identical to the original estimates (P. M. VanRaden, Animal Improvement Programs Laboratory; unpublished data), suggesting that they are reasonably robust to changes in the tipping points, although it is possible that the use of the Holstein base may affect the heritabilities of the persistency traits and their correlations with other traits. The tipping points will need updating as lactation curves change shape over time, but small changes in the definition of lactation persistency do not alter the ranking of sire PTA (data not shown).

One of the objectives of this study was the calculation of (co)variance components needed for routine evaluations of lactation persistency. Genetic evaluations for yield in the United States are calculated using a repeatability animal model, so the same model was used in this study to calculate heritabilities and repeatabilities. The advantages of test-day models over repeatability models are well known (Mrode, 2005), but their use in the United States is not currently feasible because of intellectual property concerns (Everett, 1994). However, differences among lactation curves for first- and later-parity cows could be accommodated using separate tipping points for different parity groups. The disadvantage of this approach is that lactation persistencies would be directly comparable only within a parity group.

It has been suggested that measuring variation and maximum SCC in addition to mean SCC may improve predictions of clinical mastitis (Green et al., 2004), and the value of measuring the persistency of SCS may lie in its ability to describe the pattern of SCS over the course of the lactation independently of yield. Cows with high PSCS produce more somatic cells in their milk in the second half of lactation than in the first half, and produce less milk later in lactation, which may be related to occurrence of clinical mastitis. Lactation curves for SCC differ substantially between lactations with at least one incidence of clinical mastitis and those with none, and the size of differences varies by pathogen (de Haas et al., 2002). Windig et al. (2005) found that cows with SCC peaks had higher milk yield before the peak than after, and concluded that high milk yield increases the risk of clinical mastitis. In a recent study, Appuhamy et al. (2009) reported negative genetic correlations between clinical mastitis after 100 DIM and persistency of milk yield, and the genetic correlation between PM and PSCS is negative (Table 5), suggesting that cows with high PSCS are more likely to contract clinical mastitis later in lactation.

The correlations among sire PTA for lactation persistency and fitness traits provide approximate genetic correlations. The heritability of lactation persistency is slightly higher than DPR (0.04), similar to PL (0.085), and slightly lower than the merit indices (0.20). It is possible that bulls with relatively few daughter records could have lactation persistency proofs with much different reliabilities than their fitness trait proofs. To avoid such a situation, bulls were required to have a reliability of at least $75 \%$ for the fitness trait under consideration to be included in the PTA correlations. Although this is not as formal an approach as that of Calo et al. (1973), it has been used quite satisfactorily for the formulation of the US economic indices, which are lifetime net merit, cheese merit, and fluid merit (VanRaden and Multi-State Project S-1008, 2006).

A cow with high lactation persistency (milking less than expected at the beginning of lactation and more than expected at the end of lactation) also has a longer productive life than an average cow. Correlations among the lactation persistency traits and economic indices were similar within breed, and all indicate that cows with more persistent lactations for milk and components have greater lifetime profitability than average cows. The positive genetic correlation among lactation persistency and PL may be due in part to the positive genetic correlations among lactation persistency and yield, and among yield and PL. The negative correlations between PSCS and economic merit indicate that cows with high SCS in the second half of lactation are less profitable over their lifetimes than cows with low SCS in later lactation. It must be emphasized that these results do not establish causal relationships. High lactation persistency does not necessarily cause improved longevity, but factors that favorably affect PL also affect lactation persistency.

It has been suggested that increased lactation persistency may have economic benefits resulting from improved health or reduced incidence of disease (Sölkner and Fuchs, 1987). Selection on a measure of lactation persistency that has a high genetic correlation with yield is self-defeating because of the negative association between those factors and yield, which may explain the results of Jakobsen et al. (2002), who found very small associations between persistency and liability to disease. However, Appuhamy et al. (2007) used BP in a study of disease and lactation persistency 
and concluded that disease appears to affect lactation persistency adversely rather than lactation persistency affecting disease. Harder et al. (2006) reported favorable associations between PM and fertility and foot-and-leg problems in German Holsteins, with persistent cows having lower rates of fertility and locomotion problems, but did not address the issue of causality. Calus et al. (2005) demonstrated considerable changes in genetic variance for health traits across herd environments, and relationships among lactation persistency and health may be difficult to characterize based on differential and changing patterns of use of management tools such as grazing and bST.

It was hypothesized that cows with high lactation persistency would produce more milk after $305 \mathrm{~d}$ than cows with lower persistency, but results show that lactation persistency is not providing more information about yield beyond $305 \mathrm{~d}$ than $305-\mathrm{d}$ yield alone. Cows with lactations longer than $305 \mathrm{~d}$ were allowed to continue milking for reasons that appear to be unrelated to lactation persistency. As shown in Table 3 and discussed above, the phenotypic correlations between yield and lactation persistency are not 0 in the non-Holstein breeds. This may introduce some multicollinearity into the multiple-regression model because of the correlation between the two predictors, but the same lack of predictive ability was also seen in Holsteins, the breed in which 305-d yield and lactation persistency are phenotypically uncorrelated. These results are surprising, but it is useful to know that in the populations studied 305 -d yield may be used as a highly accurate predictor of yield beyond 305 DIM.

Many lactations are now longer than $305 \mathrm{~d}$, and cows with high lactation persistency may not need a yearly calving interval to be profitable. Breed-specific prediction equations for fixed end-points, such as 100-d intervals between 305 and $999 \mathrm{~d}$, will allow producers to make better decisions about extending lactations beyond $305 \mathrm{~d}$ by providing accurate estimates of additional yield. An endpoint of $400 \mathrm{~d}$ was used to demonstrate how breed-specific prediction equations might be calculated, whereas JE data were used to determine whether or not lactation persistency had greater predictive ability as lactation length increased. Further refinement of the prediction equations may permit the use of single breed-specific equations to predict yield at any point between 305 and 999 d. Such equations will be most useful if integrated into on-farm management software.

\section{ACKNOWLEDGMENTS}

The ACCF90, BLUP90IOD, and REMLF90 computer programs were provided by Ignacy Misztal and
Shogo Tsuruta of the University of Georgia. Bennet Cassell (Virginia Tech, Blacksburg) and Paul VanRaden (Animal Improvement Programs Laboratory) provided several helpful comments on the manuscript, as did 3 anonymous reviewers.

The cooperation of the breed associations [Ayrshire Breeders' Association (Columbus, OH), American Guernsey Association (Reynoldsburg, OH), American Jersey Cattle Association (Reynoldsburg, OH), American Milking Shorthorn Society (Beloit, WI), Brown Swiss Cattle Breeders' Association (Beloit, WI), and Holstein Association USA (Brattleboro, VT)] in supplying pedigree data for registered cows and the dairy records processing centers [AgriTech Analytics (Visalia, CA), AgSource Cooperative Services (Verona, WI), Dairy Records Management Systems (Raleigh, NC, and Ames, IA), and DHI Computing Services (Provo, UT)] in supplying pedigree data for grade cows and lactation yield data are acknowledged.

\section{REFERENCES}

Appuhamy, J. A. D. R. N., B. G. Cassell, and J. B. Cole. 2009. Phenotypic and genetic relationships of common health disorders with milk and fat yield persistencies from producer-recorded health data and test day yields. J. Dairy Sci. 92:1785-1795.

Appuhamy, J. A. D. R. N., B. G. Cassell, C. D. DeChow, and J. B. Cole. 2007. Phenotypic relationships of common health disorders in dairy cows to lactation persistency estimated from daily milk weights. J. Dairy Sci. 90:4424-4434.

Calo, L. L., R. E. McDowell, L. D. VanVleck, and P. D. Miller. 1973. Genetic aspects of beef production among Holstein-Friesians pedigree selected for milk production. J. Anim. Sci. 37:676-682.

Calus, M. P. L., J. J. Windig, and R. F. Veerkamp. 2005. Associations among descriptors of herd management and phenotypic and genetic levels of health and fertility. J. Dairy Sci. 88:2178-2189.

Cole, J. B., D. J. Null, and P. M. VanRaden. 2009. Best prediction of yields for long lactations. J. Dairy Sci. 92:1796-1810.

Cole, J. B., and P. M. VanRaden. 2006. Genetic evaluation and best prediction of lactation persistency. J. Dairy Sci. 89:2722-2728.

Cole, J. B., and P. M. VanRaden. 2007. A Manual for Use of BESTPRED: A Program for Estimation of Lactation Yield and Persistency Using Best Prediction. Available: http://www.aipl. arsusda.gov/software/bestpred/docs/Best Prediction Manual.pdf. Accessed Nov. 1, 2007.

Cook, R. D., and S. Weisberg. 1998. Applied Regression Including Computing and Graphics. John Wiley \& Sons, New York, NY.

Danell, B. 1982. Studies on lactation yield and individual test-day yields of Swedish dairy cows. Acta Agric. Scand. A 32:93-101.

de Haas, Y., R. F. Veerkamp, H. W. Barkema, Y. T. Gröhn, and Y. H. Schukken. 2002. The effect of pathogen-specific clinical mastitis on the lactation curve for somatic cell count. J. Dairy Sci. 85:13141323.

Dekkers, J. C. M., J. H. Ten Haag, and A. Weersink. 1997. Economic aspects of persistency in dairy cattle. Livest. Prod. Sci. 53:237252 .

Dematawewa, C. M. B., R. E. Pearson, and P. M. VanRaden. 2007. Modeling extended lactations of Holsteins. J. Dairy Sci. 90:39243936.

Dempster, A., N. Laird, and D. Rubin. 1977. Maximum likelihood from incomplete data via the EM algorithm. J. R. Stat. Soc. B 39:1-38.

Druet, T., F. Jaffrézic, and V. Ducrocq. 2005. Estimation of genetic parameters for test day records of dairy traits for the first three lactations. Genet. Sel. Evol. 37:257-271. 
Everett, R. W. 1994. Method of bovine herd management. Cornell Research Foundation, assignee. US Pat. No. 5,351,644.

Gengler, N. 1995. Multiple-trait genetic evaluations for milk, fat, and protein yields and persistency. Interbull Bull. 11:1-6.

Gengler, N. 1996. Persistency of lactation yields: A review. Interbull Bull. 12:87-96.

Green, M. J., L. E. Green, Y. H. Schukken, A. J. Bradley, E. J. Peeler, H. W. Barkema, Y. de Haas, V. J. Collis, and G. F. Medley. 2004 Somatic cell count distributions during lactation predict clinical mastitis. J. Dairy Sci. 87:1256-1264.

Harder, B., J. Bennewitz, D. Hinrichs, and E. Kalm. 2006. Genetic parameters for health traits and their relationship to different persistency traits in German Holstein dairy cattle. J. Dairy Sci. 89:3202-3212

Jakobsen, J. H., P. Madsen, and J. Pedersen. 2002. Multivariate covariance functions for test day production in Danish dairy breeds. Interbull Bull. 29:95-102.

Jamrozik, J., G. Jansen, L. R. Schaeffer, and Z. Liu. 1998. Analysis of persistency of lactation calculated from a random regression test day model. Interbull Bull. 17:64-69.

Misztal, I. 2008. Reliable computing in estimation of variance components. J. Anim. Breed. Genet. 125:363-370.

Misztal, I., S. Tsuruta, T. Strabel, B. Auvrey, T. Druet, and D. H. Lee. 2002. BLUPF90 and related programs. Commun. No. 28-07 in Proc. 7th World Congr. Genet. Appl. Livest. Prod., Montpellier, France.

Mrode, R. A. 2005. Linear Models for the Prediction of Animal Breeding Values, 2nd ed. CABI Publishing, Cambridge, MA.

Muir, B. L., J. Fatehi, and L. R. Schaeffer. 2004. Genetic relationships between persistency and reproductive performance in first-lactation Canadian Holsteins. J. Dairy Sci. 87:3029-3037.

Rajala-Schultz, P. J., Y. T. Gröhn, C. E. McCulloch, and C. L. Guard. 1999. Effects of clinical mastitis on milk yield in dairy cows. J. Dairy Sci. 82:1213-1220.

Sölkner, J., and W. Fuchs. 1987. A comparison of different measures of persistency with special respect to variation of test-day milk yields. Livest. Prod. Sci. 16:305-319.

Strabel, T., W. Kopacki, and T. Szwaczkowski. 2001. Genetic evaluation of persistency in random regression test day model. Interbull Bull. 27:189-192.
Togashi, K., and C. Y. Lin. 2006. Selection for milk production and persistency using eigenvectors of the random regression coefficient matrix. J. Dairy Sci. 89:4866-4873.

van der Linde, R., A. Groen, and G. de Jong. 2000. Estimation of genetic parameters for persistency of milk production in dairy cattle. Interbull Bull. 25:113-116.

VanRaden, P. M. 1997. Lactation yields and accuracies computed from test day yields and (co)variances by best prediction. J. Dairy Sci 80:3015-3022.

VanRaden, P. M. 1998. Best prediction of lactation yield and persistency. Pages 347-350 in Proc. 6th World Congr. Genet. Appl. Livest. Prod., Armidale, Australia.

VanRaden, P. M. 2004. Invited Review: Selection on net merit to improve lifetime profit. J. Dairy Sci. 87:3125-3131.

VanRaden, P. M., C. M. B. Dematawewa, R. E. Pearson, and M. E. Tooker. 2006. Productive life including all lactations and longer lactations with diminishing credits. J. Dairy Sci. 89:3213-3220.

VanRaden, P. M., A. H. Sanders, M. E. Tooker, R. H. Miller, H. D. Norman, M. T. Kuhn, and G. R. Wiggans. 2004. Development of a national genetic evaluation for cow fertility. J. Dairy Sci $87: 2285-2292$

VanRaden, P. M., M. E. Tooker, J. B. Cole, G. R. Wiggans, and J. H. Megonigal Jr. 2007. Genetic evaluations for mixed breed populations. J. Dairy Sci. 90:2434-2441.

VanRaden, P. M., and Multi-State Project S-1008. 2006. Net merit as a measure of lifetime profit: 2006 revision. http://aipl.arsusda. gov/reference/nmcalc-2006.htm Accessed July 11, 2008.

Wiggans, G. R., I. Misztal, and L. D. Van Vleck. 1988. Implementation of an animal model for genetic evaluation of dairy cattle in the United States. J. Dairy Sci. 71(Suppl. 2):54-69.

Windig, J. J., M. P. L. Calus, G. de Jong, and R. F. Veerkamp. 2005 The association between somatic cell count patterns and milk production prior to mastitis. Livest. Prod. Sci. 96:291-299.

Zimmermann, E., and H. Sommer. 1973. Zum Laktationsverlauf von Kühen in Hochleistungsherden und dessen Beeinflussung durch nichterbliche Faktoren. Züchtungskunde 45:75-88. 